\title{
Reproductive Health Animations as Efforts to Prevent Sexual Harassment in Deaf Students
}

\section{Murni Winarsih ${ }^{1^{*}}$, Lussy Dwiutami Wahyuni ${ }^{2}$, Umi Nanik ${ }^{3}$}

1,2,3Special Education Program, Universitas Negeri Jakarta, Jakarta Timur, Indonesia e-mail: mwinarsih@unj.ac.id, sflussy@gmail.com,uminanikmlakas@yahoo.co.id

\begin{abstract}
This research aims to obtain information about the needs of developing reproductive health animation media to prevent sexual harassment and deviation in deaf students. The research was conducted at 14 school of special in Jakarta and West-Java Province with quantitative method. Data was taken from 105 teachers through a questionnaire and analyzed using Huberman and Miles models and the process including data reduction, data display, and verification. The results of this research obtain communication barriers which are the main cause of the ineffectiveness of sex education in deaf students can be overcome by developing reproductive health media for deaf students. So, it can be concluded that learning of reproductive health for deaf students provide a good understanding of sex education in reproductive health.
\end{abstract}

Keywords: Sexual Harassment, Animation Media, Reproductive Health.

\section{Introduction}

Efforts at protecting persons with disabilities to free from exploitation, violence, and abuse have has become a serious issue in many countries in the world. Based on the 2019 National Commission's Annual Notes 2019, Sexual violence is the most dominant form of violence against women with disabilities, as many as 64\% (57 cases), including rape (35 cases), sexual intercourse (10 cases), sexual abuse (9 cases), sexual harassment (2 cases) and attempted rape. (1 case). The cases of sexual violence against persons with disabilities increased by more than $100 \%$ from 2017 which was only 24 cases. According to United Nations Women, it is estimated that $35 \%$ of women in the world have experienced physical violence or sexual violence at some point in their lives (Hilmi, 2019).

Sexual harassment is all kinds of behavior that connote or lead to sexual things that are done unilaterally and are not expected by the target person, causing negative reactions, such as shame, anger, hatred, offense and so on (Lucarini et al., 2020; Raj et al., 2020). Sexual harassment is not only physical contact but also non-physical and verbal, such as showing the perpetrator's genitals to children, forcing children to show their genitals, showing images that are sexual in nature, besides that in the form of words, jokes, comments, and invitations that it makes the victim uncomfortable, but the cases we often hear about are only victims of physical contact which are considered serious cases (Putriningsih \& Stanislaus, 2012). Sexual harassment is classified into five categories: gender harassment (unwelcome statements and behavior to insult and to provoke negative emotions); Unwanted sexual attention (exhibiting indecent and offensive behavior); Sexual coercion (making certain requests for sexual activity by promising something or making threats) (Ramdhani, 2017; Romulo et al., 2016; Suwandi et al., 2019).

Sexual harassment can occur to persons from various social, economic, and age levels, both men and women, however women face greater risk for sexual harassment because of the views that women are physically weak. Women with disabilities are even four times more likely to

${ }^{*}$ Corresponding author.

Received 18 May 2020; Accepted 08 August 2020; Available online 01 September 2020

(C) 2020 JPI. All Rights Reserved 
experience sexual harassment than normal women (Farakhiyah et al., 2018; Findley et al., 2015; Ramdhani, 2017). Persons with disabilities are especially vulnerable to being victims of sexual harassment. The risk largely comes from those closest to them, including family members, boyfriends, disability service providers, transportation providers, other individuals with disabilities. In school and campus environments, students with disabilities experienced twice as many cases of sexual harassment by their peers as students without disabilities. Sexual harassment can take place both in public spaces in both public places and isolated places, such as in schools and campuses, workplaces, hospitals, and on public transportation (Cheung et al., 2018; Mcdonald \& Charlesworth, 2016).

Among the disability group, deaf people are among the most sexually abused. Deafness can be defined as a hearing loss that is so severe that the sufferer experiences a disturbance in processing linguistic information through hearing, with or without amplification (Cahyani et al., 2020). Speech and language skills are the main obstacles for deaf people, because they usually: have a very difficult time learning to use speech, cannot receive information through speech unless they have learned to read lip movements, and the sounds produced by deaf people difficult to understand. People who are deaf show significant problems with articulation, voice quality, and tone discrimination. Limited communication skills are a factor in the causes of perpetrators of sexual harassment to exploit persons with hearing disabilities from sexual harassment (Jones et al., 2017). Another factor is the lack of a basic understanding of sex and the limits of an act that can be categorized as sexual harassment, and the inability to understand their own bodies identified as problems related to protecting persons with hearing disabilities from sexual harassment.

In addition to reducing their risk of sexual and reproductive health problems and being exposed to sexual violence, deaf students must also learn how to refuse inappropriate, recognize and handle dangerous situations, and which people they can notify if sexual harassment occurs (Rusinga, 2012). Persons with disabilities, especially those who are deaf, are very vulnerable to becoming victims of violence, including sexual violence, rape for example in the case two priests were sentenced to more than 40 years in prison in connection with a sexual assault case in Argentina and both were found guilty of sexual harassment, including rape, of dozens of deaf children (Cahyani et al., 2020). Sex education is only provided implicitly in learning with related materials, such as in science subjects in terms of the reproductive system, through debriefing at school ceremonies, in religious lessons, or through socialization from GERKATIN (Movement for the Welfare of the Deaf Indonesia) and GAPAI (Indonesian Inclusion Care Movement). Supposedly, sex education should be provided systematically and comprehensively through an integrated curriculum.

However, there are many obstacles in providing health information to persons with hearing disabilities. In many countries, sex education is still considered a taboo subject, including in Turkey, Japan, India and Indonesia is no exception (Çuhadaroğlu, 2017; Widinarsih, 2019). Another factor is the language and communication barriers experienced by deaf people as previously described. Research conducted by (Yasin et al., 2017) stated that the teacher's level of sign language mastery as an effective medium of instruction for students with disabilities who are still at the intermediate level. This condition certainly hinders effective interaction between teachers and students, especially in explaining new terms related to reproductive health.

The use of multimedia such as the internet, video phones and e-mails can improve the ability of deaf person to communicate from afar (Suharti \& Daryono, 2020). In line with this, one of the learning media that can be used to facilitate deaf students to get information and education about sex education, especially regarding reproductive health, in this study is visual media in the form of animation. The theory that is used as the basis for this research is the combination of the theory of the dangers of sexual harassment that befell deaf students and prevention efforts through sex education with reproductive health animation media. Learning media in the form of animation is expected to be easier for deaf students to understand than students having to search 
directly from the internet. Not only positive things, sometimes through the internet students are also shown many negative things, so it would be better if lessons on reproductive health were taught through schools.

The use of relevant visual media for deaf students can increase their understanding of the media presented, facilitate learning, strengthen knowledge, explain ideas and create joy (Windasari, 2020). Research conducted by (Imawati \& Chamidah, 2018) stated that there is an increase in value after the use of Yogya Monopoli media on the subject of knowing culture in social studies subjects for deaf students of class V SLB B Karnnamanohara. The other research conducted by (Margarita \& Wahyuno, 2014) stated that macromedia flash animation media improve the quality of learning science for deaf children. this study aims to obtain information about the need for developing reproductive health animation media in order to prevent sexual harassment and deviations in deaf students. Through these media, it is hoped that deaf students can gain knowledge in order to prevent sexual harassment.

\section{Method}

Research on the prevention of the risks of sexual harassment through health animation media for deaf students uses a quantitative approach. The method of analysis was using descriptive. This research was conducted from April-June 2019 on 14 special schools in the Jabodetabek region. The instrument used in the study was a respondent test questionnaire. The questionnaire was used to see how the teacher responded to using visual learning media in the form of health learning for deaf special school students. The questionnaire contains questions about the implementation of sex education learning that has been implemented and the need for developing animation media for health education. This research was preceded by finding information about problems related to health learning. Furthermore, conducting a needs analysis, namely the health learning process that focuses on the use of existing media in the field. The next step is compiling a product design for the development of health learning media.

Data is presented in the form of a frequency distribution. The response test to the health animation media research product involved a sample of 105 teachers with hearing disabilities from 14 special schools in the Greater Jakarta area using an incidental sampling technique. This questionnaire is a means of obtaining information about the current implementation of health education and through this questionnaire animation learning media is approved for implementation in learning or not, as well as conveying about the dangers of sexual harassment and the importance of providing sex education for deaf students. The expectation that is expected from the response of the special school teachers mostly agrees, that health using animated media can provide sex education for deaf students to reduce the risk of the dangers of sexual harassment. The questionnaire measurement system in this study uses a Likert scale that has departed with 5 choices and the calculation of the score uses a frequency distribution. The poll measurement system uses a Likert scale with 5 options and its scoring calculation using the frequency distribution.

\section{Result and Discussion}

\section{Dimensions of Reproductive Health Learning Implementation}

The data presented is data from the results of the dimensional score of the implementation of reproductive health learning from 105 respondents in 14 special schools in the Jabodetabek region. The statistical description table can be seen in Table 1. 
Table 1. Frequency Distribution of Reproductive Health Learning in the Jabodetabek Region Special Schools

\begin{tabular}{cccc}
\hline Real Limits & Frequency & Percentage & Scale \\
\hline $40-46$ & 1 & 0,94 & Strongly Agree \\
$47-52$ & 20 & 19,05 & Agree \\
$53-59$ & 65 & 61,91 & Netural \\
$60-66$ & 16 & 15,24 & Strongly Disagree \\
$67-71$ & 3 & 2,86 & Disagree \\
\hline Total & $\mathbf{1 0 5}$ & $\mathbf{1 0 0}$ & \\
\hline
\end{tabular}

Data on Table 1 shows that of the 105 respondents with 18 items on the dimensions of the reproductive health program, 65 respondents (61.91\%) agreed to the implementation of learning reproductive health for deaf students and only 1 respondent $(0.94 \%)$ rated Strongly Disagree. The results of the respondent's test meant that most of the special school teachers in the Jabodetabek perceived positively to the implementation of reproductive health learning for deaf students in special schools in the Jabodetabek region.

\section{Dimensions of Reproductive Health Media Development}

The data presented is data from the results of the dimensions of reproductive health media development scores from 105 respondents in 14 special schools in the Jabodetabek area. The statistical description table can be seen in Table 2.

Table 2. Reproductive Health Media Development in the Jabodetabek Region Special Schools

\begin{tabular}{cccc}
\hline Real Limits & Frequency & Percentage & Scale \\
\hline $21-26$ & 0 & 0,00 & Strongly Agree \\
$27-31$ & 1 & 0,94 & Agree \\
$32-38$ & 31 & 29,53 & Netural \\
$39-44$ & 49 & 46,67 & Strongly Disagree \\
$45-50$ & 24 & 22,86 & Disagree \\
\hline Total & $\mathbf{1 0 5}$ & $\mathbf{1 0 0 , 0 0}$ & \\
\hline
\end{tabular}

Data on Table 2 shows 49 respondents (46.67\%) considered very much Agree on the development of reproductive health media for deaf students 1 respondent $(0.94 \%)$ rated disagree. Thus, it can be interpreted that special school teachers in the Jabodetabek area have a positive opinion about the development of reproductive health media for deaf students in special schools in the Jabodetabek region.

\section{Dimensions of Development of Animation-Based Reproductive Health Media}

The data presented is data from the results of scores related to the response to the development of animation-based media for reproductive health learning from 105 respondents in 14 special schools in Jabodetabek region. The statistical description table can be seen in Table 3.

Table 3. Overall Frequency Distribution of Responses to Animation-Based Media Development for Reproductive Health Learning in the Jabodetabek Region Special Schools

\begin{tabular}{cccc}
\hline Interval Class & Frequency & Percentage & Explanation \\
\hline $\mathbf{1 0 0 - 1 0 8}$ & 3 & 2,84 & Strongly Disagree \\
$\mathbf{1 0 9 - 1 1 7}$ & 23 & 21,91 & Disagree
\end{tabular}




\begin{tabular}{cccc}
\hline Interval Class & Frequency & Percentage & Explanation \\
\hline $\mathbf{1 1 8}-\mathbf{1 2 6}$ & 44 & 41,91 & Agree \\
$\mathbf{1 2 7}-\mathbf{1 3 5}$ & 24 & 22,86 & Strongly agree \\
$\mathbf{1 3 6}-\mathbf{1 4 4}$ & 11 & 10,48 & Strongly Agree \\
& $\mathbf{1 0 5}$ & $\mathbf{1 0 0}$ & \\
\hline
\end{tabular}

Data on Table 3 shows that 44 respondents (41.91\%) agreed with the development of animation-based media only 3 respondents (2.84\%) stated Strongly Disagree. Thus, it can be interpreted that most of the teachers of the Jabodetabek Region Special Schools perceived positively on the development of an animation-based media for teaching and learning reproductive health for deaf students. With the development of this animation-based media, it is hoped that deaf special school students can understand about sexual harassment and be able to overcome its risks.

\section{Discussion}

Equipping deaf students with sex education has proven to be a concern of special school teachers in the Jabodetabek region. Apart from being able to provide students with knowledge and understanding of growth and development related to physical, psychological, or sexual function, students are expected to be able to cope with the changes that exist within them as they age. The majority of respondents also stated their agreement that providing sexual education from an early age is a preventive effort so that students are able to control their sexual urges so that they do not fall into behavior that is detrimental to themselves or others, sexual education is also considered to prevent students from acts of sexual harassment due to their ignorance of health reproduction.

Inadequate sex education in schools and a lack of student understanding of reproductive health put students with disabilities at greater risk of sexual abuse (McDaniels \& Fleming, 2016). Sexual harassment can occur to persons from various social, economic, and age levels, both men and women, however women face greater risk for sexual harassment because of the views that women are physically weak. Women with disabilities are even four times more likely to experience sexual harassment than normal women (Farakhiyah et al., 2018; Findley et al., 2015; Ramdhani, 2017). This explains the importance of providing sex education to persons with disabilities from an early age, because sexual harassment in the long term will have negative effects such as depression and self-destruction, anxiety, feelings of inferiority and feeling tarnished, lack of selfesteem, difficulty trusting others, and sexual behavior. which is not normal.

Communication barriers are a concern for teachers in teaching deaf students, because the use of body language or sign language can be a barrier to effective delivery of material so that the use of visual media, animation, simulation is seen as the right approach to teach deaf students (Suharti \& Daryono, 2020). The use of relevant visual media for deaf students can increase their understanding of the media presented, facilitate learning, strengthen knowledge, explain ideas and create excitement. Animation media is a tool that can bridge the limitations of persons with disabilities in obtaining knowledge about reproductive health.

Equipping students with reproductive health knowledge are seen as crucial way to prevent students from acts of sexual harassment due to their ignorance of reproductive health. The increasing number of cases of sexual harassment against deaf persons has further emphasized how important it is for persons with disabilities to have information and education related to reproductive health. This is in line with the research of the (Romulo et al., 2016) stated that knowledge of reproductive health has a negative relationship with early adolescent sexual behavior, namely the higher the level of adolescent knowledge about reproductive health, the lower the sexual behavior is deviant. Therefore, reproductive health animation media for deaf students is very necessary and urgent to be developed. Animated media is seen as effective tool to reduce communication barriers in learning and effectively fostering understanding of sexual and 
reproductive health, animated media can increase student and teacher interest in learning, help and provide means to achieve learning objectives, explain new concepts or phenomena better, and be relevant to students. deaf people can improve their understanding of the material presented. The development of this animated media is also expected to reduce and prevent the occurrence of sexual harassment with deafness students, because sex education policies and programs should be developed based on scientific evidence-based theories relating to contemporary adolescent development theories (Leung et al., 2019).

The use of multimedia such as the internet, video phones and e-mails can improve the ability of deaf person to communicate from afar (Suharti \& Daryono, 2020). In line with this, one of the learning media that can be used to facilitate deaf students to get information and education about sex education, especially regarding reproductive health, in this study is visual media in the form of animation. The theory that is used as the basis for this research is the combination of the theory of the dangers of sexual harassment that befell deaf students and prevention efforts through sex education with reproductive health animation media. Learning media in the form of animation is expected to be easier for deaf students to understand than students having to search directly from the internet. Not only positive things, sometimes through the internet students are also shown many negative things, so it would be better if lessons on reproductive health were taught through schools.

The use of relevant visual media for deaf students can increase their understanding of the media presented, facilitate learning, strengthen knowledge, explain ideas and create joy (Windasari, 2020). Research conducted by (Imawati \& Chamidah, 2018) stated that there is an increase in value after the use of Yogya Monopoli media on the subject of knowing culture in social studies subjects for deaf students of class V SLB B Karnnamanohara. The other research conducted by (Margarita \& Wahyuno, 2014) stated that macromedia flash animation media improve the quality of learning science for deaf children. this study aims to obtain information about the need for developing reproductive health animation media in order to prevent sexual harassment and deviations in deaf students. Through these media, it is hoped that deaf students can gain knowledge in order to prevent sexual harassment.

\section{Conclusion}

The majority of special school teachers in the Jabodetabek region perceived positively to the development of animated media for learning reproductive health for deaf students, to foster a good understanding of sex education in reproductive health. Therefore, the development of reproductive health animation media for deaf students is very necessary and urgent to be developed in order to provide an understanding of sexual and reproductive health to deaf students.

\section{References}

Cahyani, Y. N., Verdiantoro, A. G., \& Uma, F. (2020). Perlindungan Hukum Bagi Korban Tindak Kekerasan Seksual Kaum Tunarungu Dalam Perspektif Hukum Pidana. Mimbar Keadilan, 13(2), 218-228. https://doi.org/10.30996/mk.v13i2.3941

Cheung, C., Baum, T., \& Hsueh, A. (2018). Workplace sexual harassment: exploring the experience of tour leaders in an Asian context. Current Issues in Tourism, 21(13), 14681485. https://doi.org/10.1080/13683500.2017.1281235

Çuhadaroğlu, A. (2017). The effects of sex education on psychological counselling students in Turkey. Sex Education, 17(2), 209-219. https://doi.org/10.1080/14681811.2016.1164132

Farakhiyah, R., Raharjo, S. T., \& Apsari, N. C. (2018). Perilaku Seksual Remaja Dengan Disabilitas Mental. Share: Social Work Journal, 8(1), 114-126. https://doi.org/10.24198/share.v8i1.18122 
Findley, P. A., Plummer, S. B., \& McMahon, S. (2015). Exploring the Experiences of Abuse of College Students With Disabilities. Journal of Interpersonal Violence, 1-23. https://doi.org/10.1177/0886260515581906

Hilmi, M. F. (2019). Kekerasan Seksual dalam Hukum Internasional. Jurist-Diction, 2(6), 21992218.http://dx.doi.org/10.20473/jd.v2i6.15949

Imawati, Y., \& Chamidah, A. N. (2018). Efektivitas media berbasis augmented reality terhadap kemampuan anak tunarungu mengenal kebudayaan Yogyakarta. JPK (Jurnal Pendidikan Khusus), 14(1), 26-34. https://doi.org/10.21831/jpk.v14i1.25164

Jones, C., Stalker, K., Franklin, A., Fry, D., Cameron, A., \& Taylor, J. (2017). Enablers of helpseeking for deaf and disabled children following abuse and barriers to protection: a qualitative study. Child and Family Social Work, 22(2), 762-771. https://doi.org/10.1111/cfs.12293

Leung, H., Shek, D. T. L., Leung, E., \& Shek, E. Y. W. (2019). Development of Contextuallyrelevant Sexuality Education: Lessons from a Comprehensive Review of Adolescent Sexuality Education Across Cultures. International Journal of Environmental Research and Health, 16(4). https://doi.org/10.3390/ijerph16040621

Lucarini, A., Suitner, C., Brown, R., Craig, M. A., Knowles, E. D., \& Salvador Casara, B. G. (2020). The \#MeTooLate Effect: Victim blame and trust denial for sexual harassment not immediately reported. Personality and Individual Differences, 167(July), 110240. https://doi.org/10.1016/j.paid.2020.110240

Margarita, L., \& Wahyuno, E. (2014). Penggunaan Media Animasi Macromedia Flash Untuk Meningkatkan Kualitas Pembelajaran Ipa Siswa Tunarungu Kelas li Sdlb. Jurnal Penelitian Dan Pengembangan Pendidikan Luar Biasa, 1(2), 137-139. http://journal2.um.ac.id/index.php/jppplb/article/view/4314

McDaniels, B., \& Fleming, A. (2016). Sexuality Education and Intellectual Disability: Time to Address the Challenge. Sexuality and Disability, 34(2), 215-225. https://doi.org/10.1007/s11195-016-9427-y

Mcdonald, P., \& Charlesworth, S. (2016). Workplace sexual harassment at the margins. Work, Employment \& Society, 30(1), 118-134. https://doi.org/10.1177/0950017014564615

Putriningsih, N., \& Stanislaus, S. (2012). Intensi Pekerja Rumah Tangga Korban Pelecehan Seksual Untuk Melapor. Intuisi: Jurnal Psikologi IImiah, 4(3), 123-128. https://doi.org/10.15294/intuisi.v4i3.13344

Raj, A., Freund, K. M., McDonald, J. M., \& Carr, P. L. (2020). Effects of sexual harassment on advancement of women in academic medicine: A multi-institutional longitudinal study. EClinicalMedicine, 20, 100298. https://doi.org/10.1016/j.eclinm.2020.100298

Ramdhani, I. (2017). Kasus Pelecehan Seksual Dalam Transportasi Umum Menurut Putusan Pengadilan Negeri Jakarta Pusat. SALAM: Jurnal Sosial Dan Budaya Syar-I, 4(1), 95-120. https://doi.org/10.15408/sjsbs.v4i1.7871

Romulo, H. M., Akbar, S. N., \& Mayangsari, M. D. (2016). Peranan Pengetahuan Kesehatan Reproduksi Terhadap Perilaku Seksual Remaja Awal. Jurnal Kesehatan Andalas, 1(4). https://doi.org/10.20527/ecopsy.v1i4.504

Rusinga, O. (2012). Perceptions of deaf youth about their vulnerability to sexual and reproductive health problems in Masvingo District, Zimbabwe. African Journal of Reproductive Health, 
16(2), 271-282. https://www.ajol.info/index.php/ajrh/article/view/77854

Suharti, S., \& Daryono, D. (2020). Efektifitas Video Berdialek Bahasa Jambi untuk Meningkatkan Pengetahuan tentang Penyakit HIV/AIDS pada Remaja di SMAN 8 Kabupaten Muaro Jambi. Jurnal Ilmiah Universitas Batanghari Jambi, 20(2), 418-423. https://doi.org/10.33087/jiubj.v20i2.953

Suwandi, J., Chusniatun, C., \& Kuswardani, K. (2019). Karakteristik Kekerasan Seksual Terhadap Anak Perempuan Di Wonogiri Dan Boyolali. Jurnal Pendidikan IImu Sosial, 29(1), 65-77. https://doi.org/10.23917/jpis.v29i1.8285

Widinarsih, D. (2019). Penyandang Disabilitas di Indonesia: Perkembangan Istilah dan Definisi. $\begin{array}{llll}\text { Jurnal Ilmu Kesejahteraan } & \text { Sosial, }\end{array}$ http://jurnalkesos.ui.ac.id/index.php/jiks/article/view/239

Windasari, N. (2020). Karakteristik Kasus Kekerasan Seksual di Rumah Sakit Tipe A di Jawa Barat dan Sumatera Barat. Jurnal Kesehatan Andalas, 9(2), 218-224. https://doi.org/10.25077/jka.v9i2.1308

Yasin, M. H. M., Tahar, M. M., Bari, S., \& Manaf, F. N. (2017). The Sign Language Learning in Deaf Student and Special Education Teacher in Integration Program of Hearing Problem. Journal of ICSAR, 1(2), 166-174. https://doi.org/http://dx.doi.org/10.17977/um005v1i22017p166 